\title{
National innovation system as a key factor in the sustainable development of the economy of Uzbekistan
}

\author{
Konstantin Kurpayanidi ${ }^{1,2, *}$ \\ ${ }^{1}$ Russian Academy of Natural Sciences, Moscow, Russia \\ ${ }^{2}$ Fergana Polytechnic Institute, Fergana, Uzbekistan
}

\begin{abstract}
Purpose: this article analyzes some issues of forming a modern national innovation system in the Republic of Uzbekistan as a driver of economic growth. Methods: the research tools are based on the application of General scientific research methods in the framework of a systematic approach: logical and situational analysis, expert assessments, observation, grouping, comparison. These tools were used in various combinations at different stages of the study, which allowed us to confirm the scientific consistency of the final results, conclusions and proposals. Conclusion: the authors conducted a systematic analysis of the methodology and approaches to the definition of the category "national innovation system", resulting in the author's definition of this definition. The structure of the modern national innovation system is studied by analyzing its structural elements. The place of the most significant of them in the structure of the national innovation system is determined. State regulation in the field of innovation in the Republic of Uzbekistan is considered, and the external and internal functions of the innovation system of Uzbekistan are formulated.
\end{abstract}

\section{Introduction}

In modern market conditions, one of the key factors for the sustainable growth of the national economy of the Republic of Uzbekistan is the national innovation system (NIS), which the most important tasks are to ensure a high level of competitiveness in the world stage, improve the business environment in the country and full modernization of the economy. Today, one of the main tasks are to create an efficiently functioning market sector by attracting material and financial resources to the economy, replacing worn-out fixed assets and increasing the efficiency of their use, creating a comfortable investment climate to attract private, as well as including foreign investors, preserving and increasing intellectual capital. It is the NIS, which is characterized by uncertainty today, should become the dominant and bring the country's economy to a qualitatively new level.

The present-day realities represents that the awareness of the place and role of science, as one of the main sources of innovation in the economic process, is unconditional and undeniable. Science is closely connected with all economic processes that occur within nation

*Corresponding author:w7777@mail.ru 
states, in sectors of the economy, in large corporations and in small enterprises [1, 2, 3,4,]. The issue of forming a national innovation system for the modern state is very significant and relevant, since this transformation is the guarantor of increasing the competitiveness of the economy and improving the life of society [5].

\section{Research methodology}

The article used high-quality analytical methods, expert assessment methods, scientific review, abstract-logical thinking, comparative analysis, as well as methods of induction and deduction. The study used statistical data from the Ministry of Economy and Industry of the Republic of Uzbekistan, the State Committee on Statistics of the Republic of Uzbekistan. The paper used secondary sources of information.

\section{Analysis and results}

The concept of "development" comes from the Greek word "Phusis," a concept commonly used by Homère. To get an idea on the criterion of "development," it is imperative to participate in the life of the country in order to challenge the uncontrolled development in a world where individualism and ostentatious consumption thrive; they are often described by Veblen (1979) as situations that have been forged in the race for development, leading to pollution that suffocates people, destroys nature and deteriorates the quality of life.

To determine the nature and functions of the national innovation system theory of systems should be addressed. Yu. P. Surmin, author of the widely cited textbook, writes: "Isolation and construction of the system is carried out as follows: the aim is put, that must be provided by system; defined function (or functions), which provides the implementation of function. The aim is a condition at which trend movement of the object is aimed. The goal is usually caused by a problem situation, which can not be resolved in cash. And the system is a means of solving the problem" (Fig. 1) [6].

The study of frequently cited scientists allowed the public to systematize the definition of "national innovation system" used in international practice and scientists of Uzbekistan, the CIS countries. Studies of evolution of the concept of "national innovation system" and the analysis of modern approaches to the definition of the concept allowed to formulate the following conclusions.

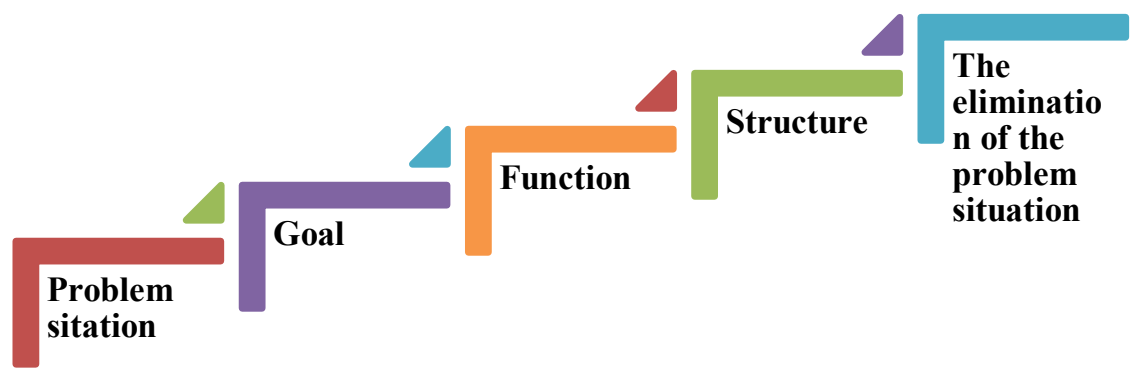

Fig. 1. Constructing system.

Firstly, to date there is no single, universally accepted concept of "national innovation system". The lack of common views stipulates different approaches to the methodology of formation of the national innovation system and its components.

Secondly, to date, there is no three main interpretations of the concept of "national innovation system", as E. V. Morgunov and G. Snegirev considers (a set of institutions, a 
complex conjugate of economic instruments and activities, a part of the national economic system [7, 7-21 p], and not four, as suggested by S. P. Lapaev (combination of different elements and components, a set of measures and mechanisms; instrument of economic policy; the control object (the state)) [8].

In the total population of approaches to the definition of the national innovation system eight directions and accordingly the authors can be distinguished, that follow these directions. Thus, the national innovation system is defined as:

- as an aggregate (set) consisting of institutions: R. Nelson, N. Rosenberg [9]; S. Metcalfe [10]; N. I. Ivanov [11]; E. V. Morgunov, G. V. Snegirev [12]; S. V. Shaposhnikova [13]; K. I. Kurpayanidi [14, 15]; S. Sh. Abdullayev, A. M. Sadykova [16]; M. K. Faizulloev [17];

- as an aggregate (set) institutions and various elements and components: C. Edquist, B. O. Lundvall [18]; P. Patel, K. Pavitt [20]; S. Faison [20]; E. M. Babosov [21].

- as a network of institutions (organizations, agencies) and targeted (directed) activities: C. Freeman [22, 23]; H. Nyosi, P. Saviotti, B. Bellon, M. Crow [24]; V. S. Bochko, E. G. Animitsa, V. N. Belkin [25]; Wolfson, S. V. [26]; L. A. Trofimova, V. V. Trofimov [27]; S. P. Lapaev [28]; F. G. Kasumov, A. D. Guseynova [29];

- as various elements, components, and the interaction between them: B. A. Lundvall [30]; N. F. Chebotarev [31];

- as part of the national economic system: A. Emelyanov [32];

- as a triple helix (the concept of knowledge production: University -Government business (enterprise, industry), formulated A. Goto [33]; N. I. Ivanov [34];

- through a broad interpretation, which includes an interdisciplinary approach: C. Edquist [35]; B. N. Kuzyk, Y. V. Yakovets [36];

- through social capital: K. Freeman, considering the national innovation system as a "social ability of the nation to technical changes"[37]; B. O. Lundvall, B. Johnson, E. S. Anderson, B. Dalum, when considering the national innovation system to explore the "interaction of the four types of capital: industrial, natural, intellectual and social"[38]; B. O. Lundvall, said that scientists have criticized "... a broad approach to the national innovation system, since the broad approach of national innovation system includes virtually everything that is in the state. It is necessary to consider social capital as well"[39]; B. O. Lundvall, B. Gregersen, B. Johnson, E. Lorenz, based on consideration of the national innovation system as the interaction between users and manufacturers in connection with the development of new products[40].

Thirdly, when considering the national innovation system, only foreign authors examine in detail the adjective "national", but does not include in the definition of the national innovation system any special characteristics of the state as a legal order in a certain territory. Uzbek scientists, adjectives "national" and "state" consider as synonyms of the word, without the emphasis on their relationship and differences. Essentially, the scientists use as synonyms both the notion of "national innovation system" and "innovation system".

None of the proposed definitions of the national innovation system, both foreign and domestic scientists, does not contain the characteristics of the state or national characteristics, implying that it is the composition and characteristics of the institutions, the various elements and components, mechanisms of interaction in the national innovation system, or public policy and allow to highlight features of national innovation system for each state.

Fourthly, in some proposed definition in detail investigated (registered) the process of "knowledge management", in some studies associated with knowledge of technologies or simply emphasized technological process.

In the process of knowledge management, attention is emphasized by: B. O. Lundvall [39, 40], Ch. Edquist [35], N. I. Ivanova [34], Yu. S. Emelyanov [32].

The technological process was highlighted in the works of C.Freeman [23]; E. V. Morgunova [12]. 
The process of knowledge management and technology was considered by following scholars: S. Metcalfe[10]; N. F. Chebotarev[31]; C. Freeman[22]; V. S. Bochko, E. G. Animitsa, V. N. Belkin[25]; L. A. Trofimova, V. V. Trofimov [27], S. P. Lapaev [28].

Fifthly, over time, scientists are developing their views on the understanding of the national innovation system. So, C. Freeman in 1987 considers the national innovation system as a network of institutions [23], and in 2002 as the nation's social capacity to make technical changes [22]. B. O. Lundvall in 2002 understands the national innovation system elements and relationships [38], and in 2007 work the focus is on the interaction of users and producers due to the development of new products, etc. [38].

In parallel with the analysis of scientific views of scientists the regulations on the subject of "national innovation system" of Uzbekistan and the countries of the Commonwealth of Independent States (CIS) was also investigated. The CIS countries have been selected as the former post-soviet space (USSR), on whose territory the common science and technology policy took place, and with the acquisition of independence of CIS countries, as well as Uzbekistan, they themselves started to determine the direction of their socio-economic development.

The analysis allowed us to formulate the following conclusions.

Firstly, to date, legal and regulatory framework of the Republic of Uzbekistan does not contain a formal definition of "national innovation system", this definition is present in the concept of innovative development of the Republic of Uzbekistan to 2020 as "a set of organizations (structures), institutions, relationships of knowledge and technologies taking into account all sectors of the economy and public life".

Secondly, the term "national" in the legal framework of the Republic of Uzbekistan is rarely used.

In the legislation of Uzbekistan, the word "national" is present in the laws "On Education", "On Defense", "On national training programs".

The word "national" is often used in combination with the word "interest". In our opinion, the national interests of Uzbekistan are understood as a set of macroeconomic and macro politic tasks of the state. National interests are provided by institutions of state power, performing its functions in collaboration with community organizations.

Thirdly, the former post-Soviet countries - 11 CIS countries - independent documents on the innovative development of the country exist only in Belarus, Kazakhstan, Kyrgyzstan and Uzbekistan. Determination of the national innovation system of the Republic of Belarus and the Russian Federation meets the definition of "innovation system" described in «The concept of innovative development of the Republic of Uzbekistan for 2012-2020». In Kazakhstan, the development of the national innovation system is provided through a regional innovation system. Kyrgyzstan has defined only the main directions of innovative development of the country.

Analysis of the evolution of the concept and the concept of "national innovation system", the concept of national innovation system and the theory of systems have allowed to define national innovation system in the classification categories of the system approach (Fig. 2).

National Innovation System in the category of:

- understanding of the system - it is a system of the universe, which is a combination of the system and its environment;

- properties of the system has: the emergence - irreducibility to the properties of the elements of the system; openness - the absence of complete isolation from the environment and the presence of degrees of freedom in the behavior of the elements;

- system status - organizational ordering system in accordance with system-factors;

- system analysis: structural analysis - analysis of the structure of the system as a set of relationships between the parts, identifying values for a single element of a structured whole 
in certain way; structural and functional analysis - selection of elements of interaction and determination of their place and role in the functioning of the system;

- variety of effects: an integrative effect - the appearance of new qualities inherent in the system as a whole; adaptability - property of the system to preserve their identity in terms of variability of the environment; a synergistic effect - the effect of multiplying the result of the system, which increases the amount of results of the functioning of its individual components;

- processes: functioning- operation of the system over time; management - bringing the system into balance or achieving goals; integration - the process and the mechanism of association and connectivity of elements; adaptation - the adaptation of the system to the environment without losing their identity;

- reflection of the system: Information - details, knowledge of observer about the system, reflection of its diversity;

- environment of the system: environment - environment system or set of objects, which are located beyond the boundaries of the system, they affect it, but do not belong to her; internal environment - a set of objects that are within the boundaries of the system, affects its behavior, but do not belong to her.

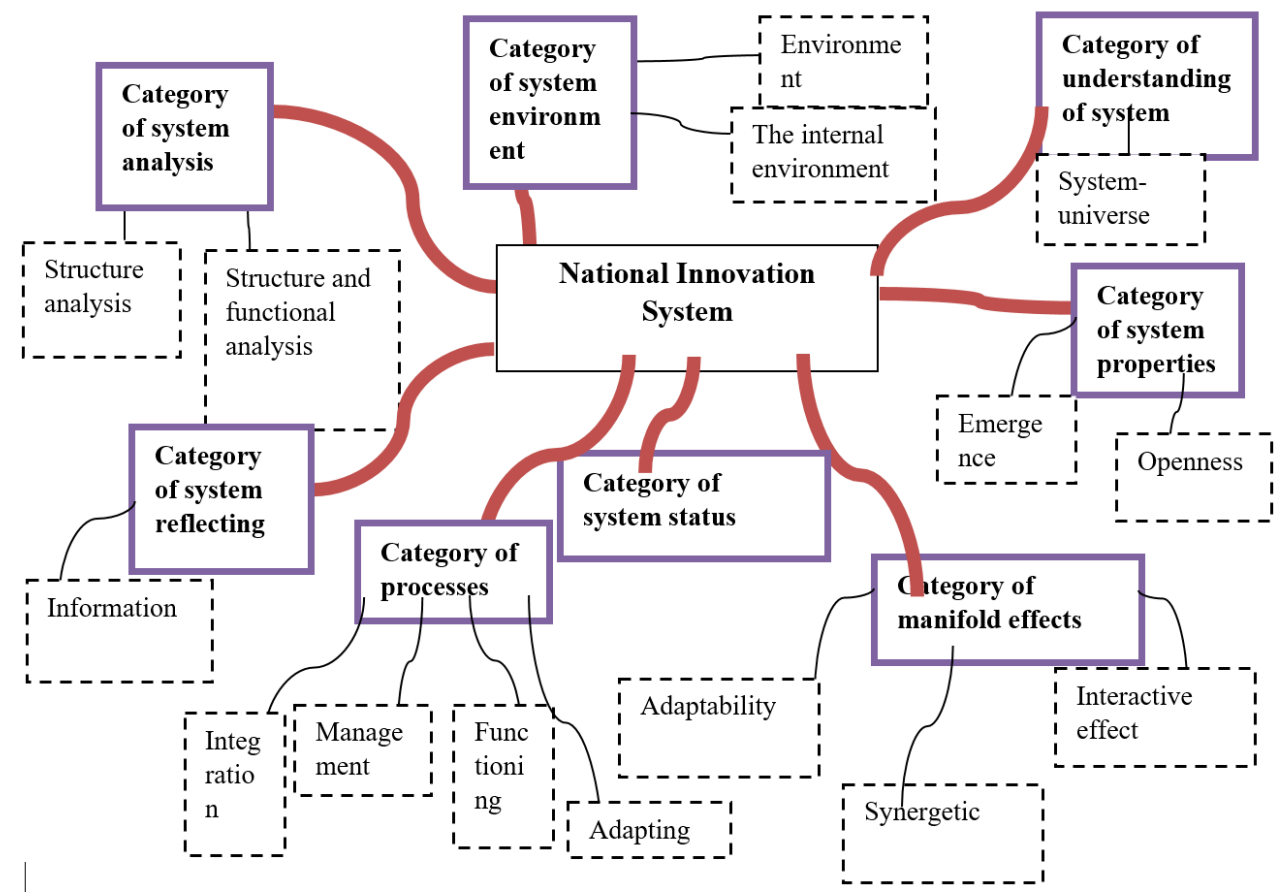

Fig. 2. The national innovation system in the classification of the categories of systematic approach.

The analysis has allowed the author to formulate a definition of "national innovation system". According to the authors of this study, the national innovation system is a complex, open, dynamic, organized system-universe, based on economic relations and the political system of the country, which regulates with norms rights of innovation processes, internal and external institutional environment for economic actors in order to preserve and increase national wealth.

The key challenge in all countries is to accelerate the technological development of the global economy, increasing competition for the factors that determine the competitiveness of national innovation systems. Based on this, the aim is to increase the level of innovation 
activity of the economy. Currently, due to the reduction of the period of realization of scientific innovations to entrepreneurs/enterprises, it is necessary to quickly respond to changing national and international needs. Rapid response can only provide a temporary advantage, as it can be used, copied, imitated by competitors in both domestic and foreign markets. Innovation activity - the most flexible indicator of status and competitiveness of the national economy.

Innovative activity is manifested through the innovative activities of economic entities (individuals and entities) operating in particular institutional environment.

In any system, including the national innovation system, there are certain functions. Analysis of the post-Soviet scientists' works allowed to count about 30 functions of the national innovation system.

Foreign scientists are more or less unanimous in allocation of functions of innovative systems and national innovation systems. Scientist of Technological University Chalmers (Sweden) A. Johnson said: "The aim of the innovation system is to develop, distribute and use innovation. There are two main features that are two directly related to the innovative process: 1) the identification of problems, bottlenecks of the innovation system;

2) the creation of new knowledge.

The third function is related to the maintenance of the innovation process and includes:

3.1) providing incentives for innovation;

3.2) providing necessary resources;

3.3) direction of search, i.e., determining strategic priorities;

3.4) determining the potential for growth of innovation;

3.5) facilitating the exchange of information and knowledge;

3.6) stimulating innovation and the creation of markets of innovation;

3.7) reduction of social uncertainty markets, i.e. preventing or resolving conflicts between companies and individuals;

3.8) counteracting resistance to changes that arise in the community with the introduction of changes, i.e. the legitimacy of the introduction of a mechanism for innovation" [41].

M. P. Hekkert and S. O. Negro in their work in 2007 are emphasizing following functions: "1) entrepreneurial activities; 2) the development of knowledge (training); 3) diffusion through the knowledge network, i.e. exchange of information; 4) guide to finding the priority areas of activity; 5) formation of the market; 6) resource mobilization; 7) establishment of legitimacy/counteraction to resist change". In their later work in 2009 they once again convincingly are limited to listed seven functions [42].

Based on the fact that:

- "function - (lat. function - fulfillment, implementation) - 1) purpose; 2) activity, duty, work";

- "functions are the directions of activity of the system that interacts with the environment";

- "function inherent in the system and its components, and functions of the system is integrated result of the operation of its constituent parts".

Following conclusions can be made.

Firstly, national innovation system is given a number of "alien" functions. For example, the formation of a national innovation policy; development and maintenance of legal and regulatory framework; the choice of priorities in the field of innovation, researches and developments etc. refer to public functions and functions of authorities of the State (which have more specific nature). Further, generation of knowledge, dissemination of knowledge, storing knowledge etc. relate to the education system.

Secondly, neither of author does not emphasize internal and external factors of the national innovation system, in spite of active development lately supranational and global processes in the world economy. 
Thirdly, as national innovation system on the category of the manifold effects has adaptability (property of the system to preserve their identity in terms of variability of the environment), the policies and actions of the state must not cause a system to have a crisis situation. National innovation system should have features like "properties in the dynamics" that lead to the implementation of goal, even in changing conditions.

Table. 1 shows the theoretical model of national innovation system, which were considered by government of Uzbekistan as a potential for use in the country:

- market and evolutionary retaining the support and financing of scientific research and technological development;

- market and radical with support and financing of only those areas of research and technological developments that are needed to implement the functions of the state;

- institutional "completion", envisaging the development of the missing elements and the spread of new forms of innovation;

- innovative and active - through the mechanism "supply creates demand," with minimal involvement of state.

Table 1. Theoretical model of development of the national innovation system features of the approaches to the implementation of the state innovation policy in foreign countries.

\begin{tabular}{|c|c|c|c|c|}
\hline Model & $\begin{array}{l}\text { Formation of } \\
\text { national } \\
\text { innovation } \\
\text { system }\end{array}$ & $\begin{array}{c}\text { Functions of the } \\
\text { state }\end{array}$ & $\begin{array}{c}\text { Features of the } \\
\text { model }\end{array}$ & Main risks \\
\hline $\begin{array}{l}\text { Market } \\
\text { Evolutionary }\end{array}$ & $\begin{array}{l}\text { Effective demand } \\
\text { generates an } \\
\text { adequate offer }\end{array}$ & $\begin{array}{l}\text { 1. Support (free } \\
\text { subsidizing) of } \\
\text { production system } \\
\text { of scientific } \\
\text { manpower, in the } \\
\text { sphere of } \\
\text { fundamental } \\
\text { research. } \\
2 \text {. Reducing } \\
\text { transaction } \\
\text { barriers on the } \\
\text { way to innovation } \\
\text { and to stimulation } \\
\text { of private demand } \\
\text { for innovation }\end{array}$ & $\begin{array}{l}\text { Structural } \\
\text { elements of the } \\
\text { NIS are created } \\
\text { and developed } \\
\text { under the } \\
\text { influence and } \\
\text { the extent of } \\
\text { effective } \\
\text { demand subjects } \\
\text { (one of which is } \\
\text { the State itself in } \\
\text { the framework } \\
\text { of its functions) }\end{array}$ & $\begin{array}{l}\text { Storing } \\
\text { segmentation } \\
\text { and incomplete } \\
\text { NIS, increasing } \\
\text { technological } \\
\text { dependence of } \\
\text { the economy on } \\
\text { foreign } \\
\text { producers of } \\
\text { technology }\end{array}$ \\
\hline $\begin{array}{l}\text { Market } \\
\text { Radical }\end{array}$ & $\begin{array}{l}\text { Effective demand } \\
\text { generates an } \\
\text { adequate offer }\end{array}$ & $\begin{array}{l}\text { Financing only } \\
\text { those areas that } \\
\text { are required to } \\
\text { implement the } \\
\text { functions of the } \\
\text { state }\end{array}$ & $\begin{array}{l}\text { The reduction of } \\
\text { the public sector }\end{array}$ & $\begin{array}{l}\text { Chance of } \\
\text { dismantling } \\
\text { national basic } \\
\text { science and } \\
\text { reduction of } \\
\text { production of } \\
\text { scientific staff }\end{array}$ \\
\hline $\begin{array}{l}\text { Institutional } \\
\text { "completion" }\end{array}$ & $\begin{array}{l}\text { Development of } \\
\text { the missing } \\
\text { elements and the } \\
\text { spread of new } \\
\text { forms of }\end{array}$ & $\begin{array}{l}\text { Statesupportof } \\
\text { NIS }\end{array}$ & $\begin{array}{l}\text { Enhanced } \\
\text { scattering of } \\
\text { budgetary } \\
\text { resources for a } \\
\text { variety of } \\
\text { existing and } \\
\text { new directions }\end{array}$ & $\begin{array}{l}\text { Automatic } \\
\text { generation of } \\
\text { competitive NIS } \\
\text { will not happen } \\
\text { due to the low } \\
\text { quality of its } \\
\text { existing } \\
\text { elements }\end{array}$ \\
\hline $\begin{array}{l}\text { Innovative } \\
\text { Active }\end{array}$ & $\begin{array}{l}\text { Supply creates } \\
\text { demand }\end{array}$ & $\begin{array}{l}\text { The increase of } \\
\text { expenses on the } \\
\text { commercialization }\end{array}$ & $\begin{array}{l}\text { Low demand for } \\
\text { innovation in } \\
\text { the business }\end{array}$ & $\begin{array}{l}\text { Lack of demand } \\
\text { on advanced }\end{array}$ \\
\hline
\end{tabular}




\begin{tabular}{|c|c|c|c|c|}
\hline & & $\begin{array}{l}\text { of advanced } \\
\text { technologies to } \\
\text { quickly bring to } \\
\text { the practical } \\
\text { applicability the } \\
\text { existing level of } \\
\text { backlog }\end{array}$ & $\begin{array}{l}\text { sector due to the } \\
\text { lack of supply of } \\
\text { innovative } \\
\text { product }\end{array}$ & $\begin{array}{l}\text { commercial } \\
\text { technologies }\end{array}$ \\
\hline $\begin{array}{l}\text { "Knowledge- } \\
\text { active" }\end{array}$ & $\begin{array}{l}\text { The focus shifted } \\
\text { to the beginning } \\
\text { of the innovation } \\
\text { cycle and on the } \\
\text { development of } \\
\text { innovative } \\
\text { education }\end{array}$ & $\begin{array}{l}\text { 1. Intense } \\
\text { investment in } \\
\text { human capital. } \\
2 . \text { "Connection" of } \\
\text { supply and } \\
\text { demand and the } \\
\text { needs of formation } \\
\text { in the various } \\
\text { innovation } \\
\text { institutes }\end{array}$ & $\begin{array}{l}\text { The creation of } \\
\text { "innovative } \\
\text { person" who } \\
\text { will be inclined } \\
\text { to innovation } \\
\text { and new } \\
\text { knowledge, } \\
\text { regardless of the } \\
\text { main areas of } \\
\text { activity }\end{array}$ & $\begin{array}{l}\text { Long term } \\
\text { perspective of } \\
\text { realization and } \\
\text { deriving effect }\end{array}$ \\
\hline
\end{tabular}

Table 2 presents main areas of modern innovation policy of foreign countries. Each country defines on its own way, through implementation of appropriate public policies, directions of functioning and development of national innovation system.

Table 2. Main directions of modern innovation policy of foreign countries.

\begin{tabular}{|c|c|c|}
\hline $\begin{array}{l}\text { Direction of innovation } \\
\text { policy }\end{array}$ & Specifics & Countries \\
\hline \multirow{3}{*}{$\begin{array}{l}\text { Optimization of the } \\
\text { structure of the national } \\
\text { innovation system }\end{array}$} & $\begin{array}{l}\text { Optimization of the system of state } \\
\text { management and planning in the field of } \\
\text { innovation }\end{array}$ & $\begin{array}{l}\text { Japan, Norway, India, } \\
\text { Chile }\end{array}$ \\
\hline & $\begin{array}{l}\text { Optimization of public funding of science } \\
\text { and innovation sphere }\end{array}$ & $\begin{array}{l}\text { USA, France, Grea } \\
\text { Britain, } \quad \text { Denmark, } \\
\text { Norway, } \quad \text { Sweden, } \\
\text { Taiwan, Australia }\end{array}$ \\
\hline & Development of basic researches & $\begin{array}{l}\text { Great Britain, Sweden, } \\
\text { Slovenia }\end{array}$ \\
\hline \multirow{4}{*}{$\begin{array}{l}\text { Stimulation of innovation } \\
\text { cooperation of business and } \\
\text { science (universities) in the } \\
\text { country }\end{array}$} & $\begin{array}{l}\text { Promoting symmetrical convergence of } \\
\text { universities and corporations }\end{array}$ & USA, Finland \\
\hline & $\begin{array}{l}\text { Large public investments in science and } \\
\text { innovation and attraction of national } \\
\text { private capital }\end{array}$ & Israel, Finland \\
\hline & $\begin{array}{l}\text { Stimulation of innovative activity of the } \\
\text { private sector with the involvement of } \\
\text { foreign capital in the innovation sphere }\end{array}$ & $\begin{array}{l}\text { UK, Ireland, China, } \\
\text { Korea, Malaysia, India, } \\
\text { Israel }\end{array}$ \\
\hline & $\begin{array}{l}\text { Stimulation of innovative initiatives of } \\
\text { research sector }\end{array}$ & $\begin{array}{l}\text { Germany, Japan, New } \\
\text { Zealand, Denmark }\end{array}$ \\
\hline \multirow{2}{*}{\begin{tabular}{|lr} 
Integration & into \\
international & innovation \\
networks &
\end{tabular}} & Complex integration & $\begin{array}{l}\text { Finland, Israel, the } \\
\text { Netherlands, China }\end{array}$ \\
\hline & technological specialization & $\begin{array}{l}\text { Korea, } \\
\text { Singapore, } \\
\text { India }\end{array}$ \\
\hline
\end{tabular}




\begin{tabular}{|c|c|c|}
\hline \multirow{2}{*}{$\begin{array}{l}\text { Establishing internal } \\
\text { innovation networks }\end{array}$} & $\begin{array}{l}\text { Creating special conditions for the } \\
\text { formation of relationships in the sphere of } \\
\text { innovation }\end{array}$ & $\begin{array}{l}\text { United States, Norway, } \\
\text { Ireland }\end{array}$ \\
\hline & Stimulating initiatives of national regions & Germany, \\
\hline \multirow{4}{*}{$\begin{array}{l}\text { The formation of the } \\
\text { national innovation system }\end{array}$} & $\begin{array}{l}\text { The restructuring of the state sector of } \\
\text { science }\end{array}$ & $\begin{array}{l}\text { Bulgaria, } \\
\text { Lithuania }\end{array}$ \\
\hline & $\begin{array}{l}\text { Initiation of the integration of science and } \\
\text { education }\end{array}$ & $\begin{array}{l}\text { Latvia, Estonia, Czech } \\
\text { Republic }\end{array}$ \\
\hline & $\begin{array}{l}\text { The involvement of small and medium- } \\
\text { sized businesses in the innovation sphere }\end{array}$ & $\begin{array}{l}\text { Romania, } \quad \text { Czech } \\
\text { Republic, Slovakia } \\
\text { Latvia, Estonia, Turkey, } \\
\text { Chile }\end{array}$ \\
\hline & $\begin{array}{l}\text { Identification of priority directions in the } \\
\text { field of export of high technology }\end{array}$ & $\begin{array}{lr}\text { Czech Republic } \\
\text { Romania, Chile, Turkey }\end{array}$ \\
\hline
\end{tabular}

Initially, the authors of this article have formulated following functions of national innovation system:

- $\quad$ legal - system provides following established by the state rules and regulations in the field of innovation, as well as feedback to improve the regulatory framework;

- resource - creating conditions for an optimal allocation of natural, production, human and social resources among all subjects of innovation activity. Tangible and intangible resources are the basis of innovative activities within the national economic system;

- function of knowledge management - the creation of conditions for the creation, transmission and storage of knowledge - creative foundation for innovation as the creation of specific activities that are unique to humans. Mediated by the action of this function is the development of human capital as the main carrier of knowledge;

- information - support and development of processes of storage, transmission and processing of information both inside the system (between the individual components, subsystems and system state as a whole), and in cooperation with national innovation system with environment (external environment, global level of development of science and technology, conditions in international processes);

- organizational - the development of forms and structures of institutions and organizations, mechanisms of their interaction, cooperation and coordination. This feature is aimed at developing diversity elements of the national innovation system and the expansion of intra-relationships;

- function of competitiveness - providing such state of economic, technological, organizational and structural efficiency, which allows the national innovation system to be competitive in the global innovation system. This ensures active cooperation of the national innovation system with the environment, aimed at a specific result;

- function of dynamic self-organization and development - determined by flowing innovative processes within the system, in particular organizational innovation, focused on the development and evolution in changing environment due to the accumulation of internal capacity. The innovative nature of flowing processes occurring in the NIS requires constant adaptation.

Analysis of the above functions as well as functions of the national innovation system, allocated by Russian scientists, and detailed study of the theory of systems changed the views of the authors. 


\section{Exterior features of the national innovation system}

Transformative function is inherent to creative systems such as national innovation system is to convert the environment, bringing it into conformity with its essence. Transformative function of the national innovation system is manifested in the preservation and increase in value and structural terms of intangible capital of the national wealth.

Consumer function is connected to the input (production) and output (consumption) of innovative products (goods, services) and is manifested through the process of innovation, or innovation activity. For the production of innovative products it is necessary to find and "grow" an innovative product (goods, services) of entrepreneur/enterprise (company), branch etc. Consumption is manifested through the finance/investment, human resources, environment infrastructure etc. On the output there should be subjects of consumption of innovative products (goods, services).

Function of absorption of the national innovation system is manifested in its relation to the supranational innovation system and the global innovation system. Companies are looking for a more favorable environment for their production around the world, according to the "new theory of international trade" and "new economic geography" by P. Krugman. Function of absorption is most clearly manifested through technological trajectory of the environment, social and network interaction, international trade agreements, international investment agreements, etc.

The adaptive function ensures coordination of the system with its environment, mutual change in behavior. In the particular case there is reference to "innovative person". National innovation system must contribute to the empowerment of people through voluntary action for innovation, innovation activity (bring the knowledge of "what, how, why"), and the person should be interested in innovation, innovation activity ("to know and participate").

As the academician of Russian Academy of Science A. I. Tatarkin mentions, "fundamental changes in social and economic system during the reforms have led to a radical transformation of the conditions of occurrence of motivational processes. A significant part of enterprises increasingly focused on a strategy of coercion, using a strong for current stage negative motive of dismissal or unemployment"[43, 10-17 pp].

Serving function of the national innovation system is shown in its top-level hierarchy as compared with:

- classification of the geography of innovation - regional, inter-regional and local innovation systems;

- functional and process classification innovation;

- $\quad$ classification of high-tech and knowledge intensive products (goods, services).

"The most important role of internal features is that they provide the necessary, for the functioning of the external system, internal dynamics" [44].

\section{Internal functions of the national innovation system}

The monitoring function is shown in qualitative and quantitative assessment and consideration of the results of the national innovation system:

- comparison of the actual status with the objectives (recognition of epochal, basis, improving innovation and pseudo-innovative);

- $\quad$ verification of compliance with the declared (control) and carried out (supervision) activities established by legislative and other normative legal requirements;

- $\quad$ avoiding the establishment of monopolistic dictate of some market participants over others.

The function of coordination and harmonization is manifested in: 
- coordinated joint actions of all components of the national innovation system, from the idea of an innovative product (good, services) to the commercialization of the product (good, services);

- horizontal ordering of components of the national innovation system.

Function of coordination dominates in the subject-subject and object-object interactions. Organizational-administrative function lies in:

- consolidation of elements and subsystems of the national innovation system of specific action of a functional in a clearly defined sequence;

- adoption of specific decisions on individual objects of the national innovation system;

- $\quad$ regulation of activity, that allows managing body to fulfill its goals and objectives.

The function of subordination (from the latin. subordinate - collateral subordination) and reordination (from the latin. reordination - reassignment) includes:

- vertical ordering of the system, where one of the constituent elements play a leading role, defining the beginning in the work of others;

- management processes in the interaction;

- legal subordination of parts or elements of a community over others, both horizontally and vertically.

Function of subordination dominates the subject-object and object-subject relationship.

Function of allocation - efficient allocation of factors of production in areas where their use will provide the greatest return.

\section{Conclusions}

Thus, on the basis of the conducted study purposeful analytical definition of the concept "national innovation system" was presented. Proposed definition of the national innovation system:

1) takes into account the fundamental components of the concept of national innovation system: theory of firm, innovation theory, theory of knowledge management, theory of systems, theory of institutionalism, theory of national wealth, theory of national economy;

2) marked complexity, openness and dynamism of the national innovation system;

3) pointed out how to use the subject of investigation in order to achieve any purpose, what are the functions performed based on.

Separation of internal and external environment of the national innovation system has allowed to formulate and justify its internal and external functions. Exterior features of the national innovation system: converting, consuming, absorbing, adaptive, serving. Internal functions of the national innovation system: controlling, coordinating and harmonizing, organizational and administrative, subordinating and reordinating, allocating.

\section{References}

1. C. Freeman, Research policy 31(2), 191-211 (2002)

2. M.P. Hekkert, R.A. Suurs, S.O. Negro, S. Kuhlmann, R.E. Smits, Technological forecasting and social change 74(4), 413-432 (2007)

3. E.S. Margianti, M.A. Ikramov, A.M. Abdullaev, Entrepreneurship in Uzbekistan: trends, competitiveness, efficiency (Gunadarma Publisher, Indonesia, Jakarta, 2016)

4. E.S. Margianti, M.A. Ikramov, A.M. Abdullaev, K.I. Kurpayanidi, A.Sh. Khudaykulov, Role of goal orientation as a predictor of social capital: Practical suggestions for the development of team cohesiveness (Gunadarma Publisher, Indonesia, Jakarta, 2020) 
5. E.S. Margianti, M.A. Ikramov, A.M. Abdullaev, Entrepreneurship in Uzbekistan: trends, competitiveness, efficiency (Gunadarma Publisher, Indonesia, Jakarta, 2016)

6. L.A. Trofimova, V.V. Trofimov, Innovacionnye podhody $k$ prinjatiju upravlencheskih reshenij: uchebnoe posobie (Sankt-Peterburgskij gosudarstvennyj universitet Jekonomiki i Finansov, 2012)

7. E.V. Morgunov, G.V. Snegirev, Sobstvennost' i rynok 7, 10-21 (2009)

8. S.P. Lapaev, Vestnik Orenburgskogo gosudarstvennogo universiteta 8, 110-118 (2013)

9. R.R. Nelson, N. Rosenberg, National innovation systems: A comparative analysis 1, 321 (1993)

10. S. Metcalfe, The economic foundations of technology policy: equilibrium and evolutionary perspectives. Handbook of the economics of innovation and technological change (1995)

11. V.V. Ivanov, Innovacii 5 (2010)

12. E.V. Morgunov, G.V. Snegirev, Sobstvennost' i rynok 7, 10-21 (2009)

13. S.V. Shaposhnikova, Innovacionnyj vestnik Region 4, 27-31 (2008)

14. K. Kurpayanidi, D. Mamurov, Bulletin of Science and Practice 5(11), 255-261 (2019) https://doi.org/10.33619/2414-2948/48/29

15. K.I. Kurpayanidi, A.M. Abdullaev, ISJ Theoretical \& Applied Science 11(67), 74-81 (2018) Doi: https://dx.doi.org/10.15863/TAS.2018.11.67.14

16. Sh.S.O. Abdulaev, D.A. Denevizjuk, A.M. Sadykova, Regional'nye problemy preobrazovanija jekonomiki 7, 45 (2014)

17. M.K. Fajzulloev, Formirovanie i razvitie nacional'noj innovacionnoj sistemy Respubliki Tadzhikistan (metodologicheskie podhody i mehanizm upravlenija): avtoref. dis. d-ra jekon. nauk (M., 2012)

18. C. Edquist, African Journal of Science, Technology, Innovation and Development 2(3), 14-45 (2010) https://charlesedquist.files.wordpress.com/2015/04/systems-ofinnovation-perspectives-and-challenges-oxford-handbooks.pdf

19. Parimal Patel, Keith Pavitt, Economics of Innovation and New Technology 3 (1994) https://doi.org/10.1080/10438599400000004

20. S. Feinson, Columbia University National Innovation Systems Overview and Country Cases 1(1) https://cspo.org/legacy/library/110215F4ZY_lib_FeinsonInnovatio.pdf

21. E.M. Babosov, F.I. Khramtsova, Post-Soviet Issues 2, 5-22 (2016) https://www.postsovietarea.com/jour/article/view/74/75

22. C. Freeman, Research policy 31(2), 191-211 (2002) https://doi.org/10.1016/S00487333(01)00136-6

23. C. Freeman, Research Policy 17(5), 309-310 (1988) https://doi.org/10.1016/00487333(88)90011-X

24. J. Niosi, P. Saviotti, B. Bellon, M. Crow, Technology in Society 15(2), 207-227 (1993) https://www.scopus.com/record/display.uri?eid=2-s2.00000326836\&origin=inward\&txGid=248116a050af4cb905970ba07587ed00

25. V.S. Bochko, E.G. Animitsa, V.N. Belkin, Regional problems of formation of the national innovation system (Institute of Economics, Ural branch of the Russian Academy of Sciences, Yekaterinburg, 2004)

26. S.V. Wolfson, Vestnik Tomskogo gosudarstvennogo universiteta istoriya-tomsk state university journal of history 53, 112-115 (2018) 
27. L.A. Trofimova, V.V. Trofimov, Knowledge management: a textbook (Spbsuef publishing house, $\mathrm{SPb}, 2012$ )

28. M.G. Lapaeva, S.P. Lapaev, Region as a Spatial Socioeconomic System of the State (2012) http://vestnik.osu.ru/2012_8/21.pdf

29. F.G. Kasumov, A.D. Huseynova, National innovation system and its information support: textbook (Publishing house As Gard, Samara, 2013)

30. B.A. Lundvall, Industry and innovation 14(1), 95-119 (2007) https://doi.org/10.1080/13662710601130863

31. N.F. Chebotarev, Innovation policy and human capital in the oil and gas industry of the Russian fuel and energy sector, monograph (ROS. state University of oil and gas named after I. M. Gubkina, Prospect, Moscow, 2018) https://rucont.ru/efd/673083

32. A.A.B. Emel'anov, N.V. Gorodnav, A.A.A. Peshkova, D.S. Voronov, It's a great method to assess the efficiency of the realiscii proectsof the gosudstnyhpartyh partnerstv (Gazette NGUJeU, 2018)

33. A. Goto, Oxford Review of Economic Policy 16(2), 103-113 (2000)

34. V.V. Ivanov, Innovation 5 (2010)

35. C. Edquist, B.A. Lundvall, National innovation systems: A comparative analysis, 265298 (1993)

36. B.N. Kuzyk, Y.V. Yakovets, Russia-2050: strategy of innovative breakthrough (2005)

37. C. Freeman, Research policy 31(2), 191-211 (2002) https://doi.org/10.1016/S00487333(01)00136-6

38. B.Å. Lundvall, B. Johnson, E.S. Andersen, B. Dalum, Research policy 31(2), 213-231 (2002)

39. B.A. Lundvall, Industry and innovation 14(1), 95-119 (2007) https://doi.org/10.1080/13662710601130863

40. B.Å. Lundvall, B. Gregersen, B. Johnson, E. Lorenz, Innovation systems and economic development (2016)

41. A. Johnson, Nelson and Winter Conference, Aalborg, Denmark 6, 12-15 (2001)

42. M.P. Hekkert, S.O. Negro, Technological forecasting and social change 76(4), 584-594 (2009) https://doi.org/10.1016/j.techfore.2008.04.013

43. A.I. Tatarkin, Innovation 3, 10 (2013)

44. J.P. Surmin, Theory of systems and system analysis (MAUP, K., 2003) 